\title{
Review Article \\ Synthetic Methods, Chemistry, and the Anticonvulsant Activity of Thiadiazoles
}

\author{
Bhawna Sharma, ${ }^{1}$ Amita Verma, ${ }^{2}$ Sunil Prajapati, ${ }^{1}$ and Upendra Kumar Sharma ${ }^{1}$ \\ ${ }^{1}$ Institute of Pharmacy, Bundelkhand University, Jhansi 284128, India \\ ${ }^{2}$ Department of Pharmaceutical Sciences, Faculty of Health Sciences, Sam Higginbottom Institute of Agriculture, \\ Technology and Sciences-Deemed University, Allahabad 211007, India
}

Correspondence should be addressed to Bhawna Sharma; bms1928@yahoo.com

Received 5 December 2012; Revised 8 February 2013; Accepted 12 February 2013

Academic Editor: Hussein El-Subbagh

Copyright (C) 2013 Bhawna Sharma et al. This is an open access article distributed under the Creative Commons Attribution License, which permits unrestricted use, distribution, and reproduction in any medium, provided the original work is properly cited.

\begin{abstract}
The chemistry of heterocyclic compounds has been an interesting field of study for a long time. Heterocyclic nucleus 1,3,4thiadiazole constitutes an important class of compounds for new drug development. The synthesis of novel thiadiazole derivatives and investigation of their chemical and biological behavior have gained more importance in recent decades. The search for antiepileptic compounds with more selective activity and lower toxicity continues to be an active area of intensive investigation in medicinal chemistry. During the recent years, there has been intense investigation of different classes of thiadiazole compounds, many of which possess extensive pharmacological activities, namely, antimicrobial activity, anticonvulsant, antifungal antidiabetic, anti-inflammatory, antioxidant, and antituberculosis activities, and so forth. The resistance towards available drugs is rapidly becoming a major worldwide problem. The need to design new compounds to deal with this resistance has become one of the most important areas of research today. Thiadiazole is a versatile moiety that exhibits a wide variety of biological activities. Thiadiazole moiety acts as "hydrogen binding domain" and "two-electron donor system." It also acts as a constrained pharmacophore. On the basis of the reported literature, we study here thiadiazole compounds and their synthetic methods chemistry and anticonvulsant activity.
\end{abstract}

\section{Introduction}

Epilepsy is the name of a brain disorder characterized predominantly by recurrent and unpredictable interruptions of normal brain function, called epileptic seizures $[1,2]$. The current therapy of epilepsy with antiepileptic drugs is associated with side effects, dose-related and chronic toxicity, and teratogenic effects $[3,4]$. Epilepsy is not a singular disease entity but a variety of disorders reflecting underlying brain dysfunction that may result from many different causes. Therefore, there is continuing demand for new anticonvulsant agents. So, there is an urgent requirement for the dieovery and development of some novel anticonvulsant agents with more selective activity and lower toxicity for the effective treatment of epilepsy. Several five-membered aromatic systems having three heteroatoms at symmetrical positions such as thiadiazoles have been studied extensively owing to their interesting pharmacological activities. There is a broad variety of heterocyclic compounds which are having medicinal importance, and recently, much attention has been focused on thiadiazole derivatives in view of their broad spectrum activities. Thiadiazole is one such heterocyclic nucleus. There are several isomers of thiadiazole, that is 1,2,3-thiadiazole, 1,2,4-thiadiazole, 1,2,5-thiadiazole, and 1,3,4-thiadiazole [5], 1,3,4-Thiadiazole is the main isomer of thiadiazole series having versatile pharmacological activities.

\section{Thiadiazole}

Thiadiazole is a heterocyclic organic compound that has a five-member ring having one sulphur and two nitrogen atoms [6]. 1,3,4-Thiadiazoles represent one of the most biologically active classes of compounds, possessing a wide spectrum of activities. Thiadiazoles have become very important 
TABLE 1: Physical properties of 1,3,4-thiadiazole.

\begin{tabular}{lccc}
\hline \multicolumn{2}{c}{ Bond length } & \multicolumn{2}{c}{ Bond angle } \\
Type & $\AA$ & Type & $\left(^{\circ}\right)$ \\
\hline $\mathrm{a}$ & 1.371 & $\alpha$ & 112.2 \\
$\mathrm{~b}$ & 1.302 & $\beta$ & 114.6 \\
$\mathrm{c}$ & 1.721 & $\gamma$ & 86.4 \\
$\mathrm{~d}$ & 1.721 & $\delta$ & 114.6 \\
$\mathrm{e}$ & 1.302 & $\varepsilon$ & 112.2 \\
\hline
\end{tabular}

compounds in medicine, agriculture, and many fields of technology. A large number of 1,3,4-thiadiazoles have been patented in the agricultural field as herbicides and bactericides [7].

$\mathrm{X}$-ray analysis shows the following structure parameter for 1,3,4-thiadiazole ring (see Table 1 and Structure (1)):

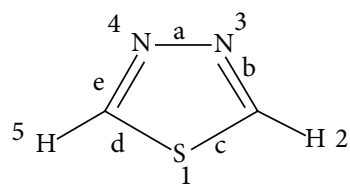

(1)

\section{Chemistry of Thiadiazole}

A recent literature survey revealed that the 1,3,4-thiadiazole moiety has been widely used by the medicinal chemist in the past to explore its biological activities. The development of 1,3,4-thiadiazole chemistry is linked to the discovery of phenylhydrazines and hydrazine in the late nineteenth century. The first 1,3,4-thiadiazole was described by Fischer in 1882 , but the true nature of the ring system was demonstrated first in 1890 by Freund and Kuh.

Thiadiazole is a five-member heterocyclic compound having one sulphur and two nitrogen atoms. There are several isomers of thiadiazole, that is, 1,2,3-thiadiazole (2), 1,2,5thiadiazole (4), 1,2,4-thiadiazole (3), and 1,3,4-thiadiazole (5). There are four possible systems in thiadiazole.

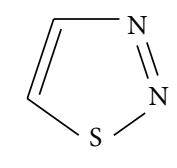

1,2,3-thiadiazole

(2)

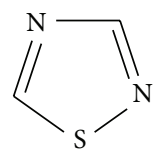

1,2,4-thiadiazole

(3)

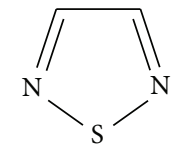

1,2,5-thiadiazole

(4)<smiles>c1nncs1</smiles>

1,3,4-thiadiazole

(5)

\section{1,3,4-Thiadiazoles}

1,3,4-Thiadiazole was first described in 1882 by Fischer and further developed by Bush and his coworkers, but true nature of the ring system was demonstrated first in 1956 by Goerdler et al. [8]. The advent of sulphur drugs and the later discovery of mesoionic compound greatly accelerated the rate of progress in the field of thiadiazole. Thiadiazole carrying mercapto, hydroxyl, and amino substituents can exist in many tautomeric forms. The 1,3,4-thiadiazoles are conveniently divided into three subclasses:

(a) aromatic systems which include the neutral thiadiazoles and constitute a major part of this paper;

(b) mesoionic systems which are defined as fivemembered heterocycles which are not covalent or polar and possess a sextet of electrons in association with the five atoms comprising the ring;

(c) nonaromatic systems such as the 1,3,4-thiadiazoles and the tetrahydro 1,3,4-thiadiazoles. In the partially reduced systems, the position of the double bond is denoted by the prefix $\Delta$, with being a $\Delta^{2}-1,3,4$ thiadiazole (Structures (6), (7), and (8)).<smiles>C1=NNCS1</smiles>

(6)<smiles>C1N=NCS1</smiles>

(7)<smiles>C1NNCS1</smiles>

(8)

\section{Synthetic Procedures of 1,3,4-Thiadiazoles}

(a) Formation of One Bond. The most common procedure for the synthesis of 5-substituted 2-amino-thiadiazole 


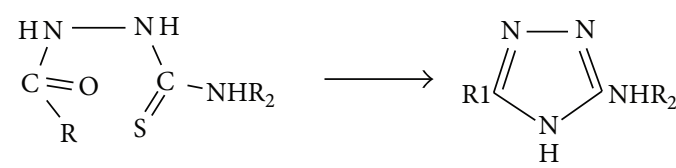

(9)

SCHEME 1

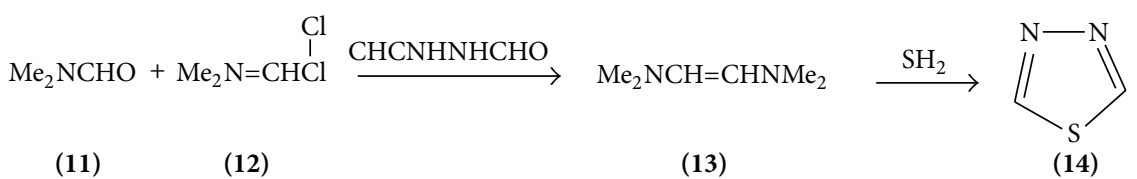

SCHEME 2

is the acylation of a thiosemicarbazide followed by dehydration. Sulphuric acid, polyphosphoric acid, and phosphorous halides are some of the reagents used. The most recent procedure utilizes 1.5 moles of methane sulphonic as a dehydrating agent and the thiadiazoleare obtained in the high yield and good purity. 5-Alkyl-2-methyl amino-1,3,4thiadiazoles are prepared from a suitable carboxylic acid and methyl thio-semicarbazide in the presence of three parts of polyphosphoric acid and one part of concentreted sulphuric acid. 2-alkylamino-1,3,4-thiadiazole $n$ substituted in the 5th position can be prepared in high yields by the reaction of 4-alkylthiosemicarbazides with orthoformate esters in the presence of small amount of concentreted hydrochloric acid [9] (Scheme 1).

(b) Formation of Two Bonds. This is the most widely used procedure for the synthesis of thiadiazoles, thiazolidines, and mesoionic thiadiazoles.

(1) Cyclization. The parent molecule 1,3,4-thiadiazole was synthesized in 1956 by a four-step reaction sequence start utilizing hydrazine and from thiosemicarbazide. A second procedure utilizes hydrazine and potassium dithioformate. Dehydration of DMF with thionyl chloride or phosgene gives the formamide chloride which on treatment with $\mathrm{N}, \mathrm{N}^{\prime}$ Diformylhydrazine gives the dihydrochloride of the free base which is liberated with sodium ethoxide, which then cyclizes to thiadiazole in the presence of hydrogen sulphide in an overall yield of 65\%. 2-Amino 1,3,4-thiadiazole is also prepared from thiosemicarbazide and a mixture of formic and hydrochloric acid in a tedious procedure with an overall yield of $65 \%$ (Scheme 2).

(2) Dipolar Cycloadditions. This procedure has been widely used during the last decade for both synthetic and mechanistic reasons.

From Diazo Compounds. The reaction of aryl sulphonylsubstituted sulfines with diazomethane gives $\Delta^{3}$-1,3,4-thiadiazole 1-oxide which, however, is unstable and rearranged via an isomerization of the $\Delta^{3}$ to the $\Delta^{2}$-thiadiazole oxide. This is followed by an elimination and readdition of sulfonic acid and loss of water in a pummerer-type aromatization to give the rearranged thiadiazole (Scheme 3 ).

\subsection{Method of Synthesis of 1,3,4-Thiadiazole}

(a) From Hydrazine. 3-Thiocarbamoyl thione methyl carbonate on oxidation with $\mathrm{H}_{2} \mathrm{O}_{2}$ gave alkoxythiadiazole [10] (Scheme 4).

(I) Thiobenzoyl hydrazine cyclized to produce 1,3,4thiadiazole-thiobenzoyl hydrazine [11] (Scheme 5).

(II) Thione carbazate are cyclized by cyanogens chloride or bromide to give 1,3-thiadiazole [12] (Scheme 6).

(b) From Semicarbazide. When 4-phenyl-1-(thiobenzole) semicarbazide reacts in the presence of concentreted $\mathrm{HCl}$ giving 2-hydroxyl-5-phenyl-1,3,4-thiadiazole [13] (Scheme 7).

(c) From Thiosemicarbazide. Many syntheses of the 1,3,4thiadiazole proceed from thiosemicarbazide or substituted thiosemicarbazide.

Method 1. Gupta et al. have shown that thiosemicarbazide cyclizes directly to 2-amino-5-diazole with acetyl chloride. This simple route to 2-amino 5-substituted-1,3,4-thiadiazole seems to be quite general. In the example shown, $\mathrm{R}$ may be methyl17, nor hydnocarpyl, benzyl, cyclopropyl [14], and many others (Scheme 8).

(d) From Thiosemicarbazone. 2-Amino-5-substituted thiadiazoles are prepared by oxidative cyclization of thiosemicarbazones with ferric chloride found 1,3,4-thiadiazole [15] (Scheme 9).

(e) From Resin. Resin with TMSCl, MCPBA, and $\mathrm{R}^{2} \mathrm{R}^{3} \mathrm{NH}$ gave 1,3,4-S thiadiazole [16] (Scheme 10).

(f) From Bithioureas. Bithiourea and substituted bithiourease have been converted to 1,3,4-thiadiazole by several methods. 
<smiles>[R20]O[R16]([R20])([H])C1([R10])C[C@H](C=C)N=N1</smiles>

(16)
(17)
(18)
(19)

SCHEME 3<smiles>COC=CC(N)O</smiles>
(20)

(21)
Method 1. Bithiourea when treated with 3\% hydrogen peroxide is cyclized to 2,5-diamino-1,3,4-thiadiazole (Scheme 11).

Method 2. Acetic anhydride acts on bithiourea to form a diacetyl derivative of 2,5-diamino-1,3,4-thiadiazole. The acetyl group I is easily removed by hydrolysis to give the parent thiazole [17].

\subsection{Chemical Properties}

5.2.1. Reactivity. Some of the characteristic reactions of the 1,3,4-thiadiazole nucleus are ring opening by strong base ease of nucleophilic attack and the formation of mesoionic compounds by quaternization. The substituents in the 2 and 5 positions have a large effect in determining the reactivity of the molecule as a whole. Thus, the ambient nucleophilicity of 2 -aminothiazoles gives rise to electrophilic attack on both the amino group and the nuclear nitrogen atom. Ring formation between these two nitrogen atoms is also a common reaction. 2-Mercaptothiazoles react similarly to arenethiols while a methyl group on the thiadiazole ring has reactivity similar to that in a picoline. Nucleophiles easily displace halogen atom from the thiadiazole nucleus. This is due to the electronegativity of the two nuclear nitrogen atoms which impart a low electron density to the carbon atom of the nucleus.

5.2.2. Thermal and Photochemical Reactions. Thermal and photochemical fragmentations of 1,3,4-thiadiazole often follow the fragmentation pattern observed in the mass spectrometer. The cis-2,5-di-t-butyl-2,5-dihydro-1,3,4-thiadiazole gives while photolysis yields the katazine. The cis 2,5dihydro-1,3,4-thiadiazole 1,1-dioxide (cis-4) undergoes thermolysis at $50^{\circ} \mathrm{C}$ to give the azine. The trans isomer (trans4), however, undergoes thermolysis only above $145^{\circ} \mathrm{C}$ to give the alkylidine hydrazide plus sulphur monoxide which disproportionate into sulphur dioxide. Compounds were independently prepared from dimethylpropanyl, and the hydrazole thermolysis of the isomeric 2,3-dihydro-1,3,4thiazole 1,1-thiadiazole 1,1 dioxide also gives rise. The concerted $[4+1]$ cycloelimination of sulphur dioxidefrom the trans isomer cannot take place due to steric hindrance (Scheme 12).

(1) Reaction with Electrophile. Because unsaturation rings have excessive $\pi \mathrm{e}^{-}$, the two nitrogen atoms $\mathrm{e}^{-}$are pulled towards them and ring carbon atoms remain with low $\mathrm{e}^{-}$density and consequently no electrophilic substitution possible in unsubstituted 1,3,4-thiadiazole ring.

(a) Attack at Ring Nitrogen (Quaternization). Ratio of 3 or 4 substituted product depends on ring substitution, in which nitrogen has high $\mathrm{e}^{-}$density (Scheme 13).

(b) Electrophilic Attack at Carbon. Due to the electron density at the carbon atoms in 1,3,4-thiadiazole, such reaction as nitration, acetylation, sulphonation, halogenations. However, 2-amino-substituted 1,3,4-thiadiazoles (1a-i) heat with bromine in acetic acid to give 5-bromo derivatives (2a-i). Similarly, the thiadiazoles $(3 \mathrm{~b})$ yield $(3 \mathrm{~d}-\mathrm{f})$ the corresponding 5-bromo derivatives (4b) and (4d-f) (Scheme 14).

(c) Electrophilic Attack at Sulphur. Although direct oxidation at sulphur atom in 1,3,4-thiadiazoles has not been reported, $\Delta^{3}$ 1,3,4-thiadiazole 1-oxides and 1,1 dioxides can be indirect mean (Scheme 15).

(d) Electrophilic Substitution at Ring. Strong e ${ }^{-}$donar substituted at ring position 2 activates towards electrophilic agents under drastic condition (conc. $\mathrm{H}_{2} \mathrm{SO}_{4}+$ fuming $\mathrm{HNO}_{3}$ ).

Nitration of 2 ammonia 1,3,4-thiadiazoles with fuming nitric acid at $40^{\circ} \mathrm{C}$ gave 2 -amino-1,3,4-thiadiazoles (21A) (Scheme 16).

5.3. Amination. Direct nuclear amination of certain thiadiazoles is possible, illustrating the case of nucleophilic attack. $(\mathrm{R}=\mathrm{H})$ react with hydroxylamine in the presence of base to give $\left(\mathrm{R}=\mathrm{NH}_{2}\right)$ presumably via the imine (Scheme 17).

(III) Nucleophilic Attack. 1,3,4-Thiadiazole ring reacts with strong nucleophiles, treatment of the parent compound with base leading to ring fission. 2-Amino and 2-methylamino 1, 3, 4-thiadiazole rearrange in the presence of methylamine to the triazolinethione (Scheme 18). 


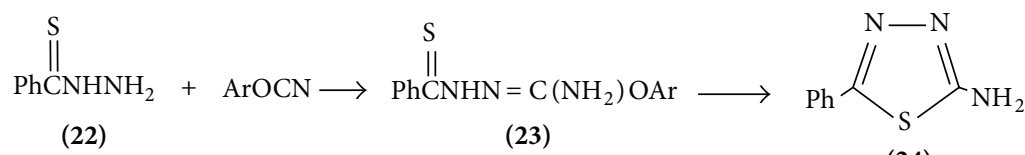

(24)

SCHEMe 5<smiles>[R20]NC(=S)[NH2+][CH]NC[R20]c1nnc(N)s1</smiles>

(25)

(26)

SCHEMe 6<smiles>O=C(NNC(=S)c1ccccc1)c1ccccc1</smiles>

(27)

(28)

Scheme 7<smiles>[R]C(=O)[NH2+]C(=S)NN</smiles>

(29)

(30)

(31)

SCHEMe 8<smiles>C[PH2+][R](C)c1nncs1</smiles>
(32)

$\mathrm{R}=\mathrm{Ar}, \mathrm{ArCO}, \mathrm{CH}_{3} \mathrm{CO}, \mathrm{EtCO}$

SCHEMe 9<smiles>[R]C(=O)NNC(=S)SCOC</smiles>

$\underset{\text { (2) } \mathrm{MCPBA}}{\stackrel{\text { (1) }}{\longrightarrow}}$

(3) $\mathrm{R}^{2} \mathrm{R}^{3} \mathrm{NH}$<smiles>[R]N([Y])C1=NN=C[Sb]1[R]</smiles>

(35)

Scheme 10<smiles>NC(=S)NC(N)=S</smiles>

(36)
(2) Nucleophilic Substitution. Due to the electronegativity of the two nitrogen atoms in the ring, the carbon atom has low electron density and gives many possible nucleophilic reactions [18]. Halogenate 1,3,4-thiadiazoles are important intermediates in which the halogen atom is readily by nucleophiles. 5-Chloro-thiadiazole reacts readily with nucleophiles to give a series of 5 substituted-2-aryl-1,3,4thiadiazoles (Scheme 19).

Amino thiadiazoles are rather weak bases; they are nucleophilic enough to be readily acetylated by acid chlorides or acetic acids (Scheme 20).

Aminothiadiazole forms diazonium salts and shows the coupling activity [19] (Scheme 21).

2-Amino-1,3,4-thiadiazoles and aromatic aldehydes form shiff bases [20] (Scheme 22).

5.4. Miscellaneous Reaction. Direct introduction of mercapto group on 2-phenyl-1, 3, 4-thiadiazoles is possible by the use of phosphorous pentasulphide [21] (Scheme 23).

5.4.1. Reduction of Thiadiazole Ring. 2-Amino-1,3,4-thiadiazoles reduces to benzaldehyde thio semicarbazone [22] (Scheme 24).

5.4.2. Reaction Involving Formation. On heating, 2-amino thiadiazole reacts with many dicarbonyl group containing compounds and forms various types of rings attached to thiadiazole (Scheme 25).

5.4.3. Rearrangement Reaction. Various 2-chloro and 2amino substituted thiadiazoles undergo rearrangement by ring opening intermediate formation and again ring closure to form $4 \mathrm{~N}$ substituted 1,3,4-thiadiazole 5(1)-terione [23, 24] (Scheme 26).

(a) Dimorph Rearrangement. See Scheme 27.

(b) Under Same Condition. See Scheme 28.

(c) Acid Catalysed. See Scheme 29.

(d) Cycloaddition Reaction. Aminobenzothiadiazoles are produced when 1,3,4-thiadiazoleinethiones $\left(R^{1}=H, M e, A c\right.$, $\mathrm{R}^{2}=\mathrm{Me}, \mathrm{Ph}$ ) are reacted with benzyne, most likely by a 1,3-dipolar addition mechanism followed by elimination of RSCN (Scheme 30).

5.4.4. Reaction of Constituents on Carbon. Treatment of 2-methyl 1,5 diphenyl-1-1,3,4-thiadiazole $(\mathrm{R}=\mathrm{H})$ with $n$ butyllithium at $-78^{\circ} \mathrm{C}$ gives the lithio derivative $(\mathrm{R}=\mathrm{Li})$ 


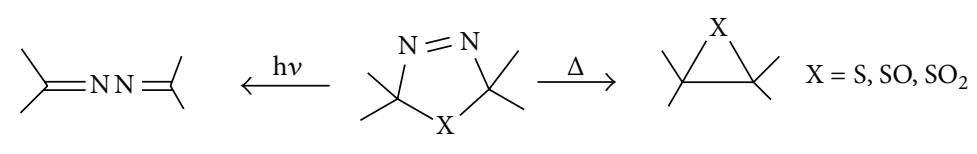

(38)

(39)

(40)

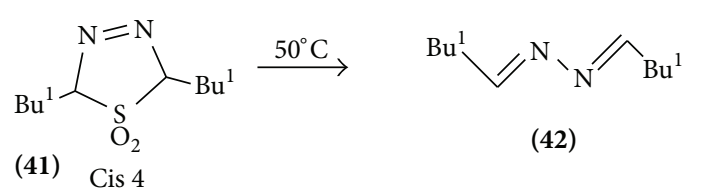

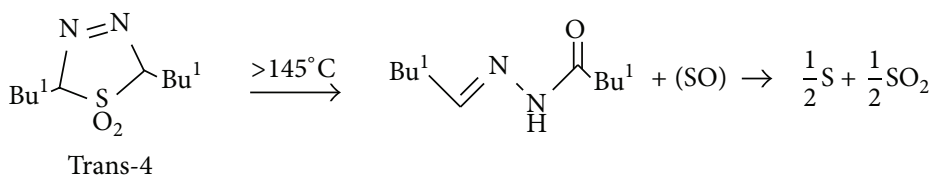

(43)

SCHEMe 12<smiles>[R2]c1nnc([18F])s1</smiles>

(45)<smiles>[R]c1n[n+](C)c([R7])s1</smiles>

(46)<smiles></smiles>

(47)

SCHEME 13

which, on treatment with methyl iodide, gives the expected 2-ethyl homologue $(\mathrm{R}=\mathrm{Me})$; if $(\mathrm{R}=\mathrm{Li})$ is allowed to warm from $-78^{\circ} \mathrm{C}$ to $25^{\circ} \mathrm{C}$ the dimer is formed, which on heating above $150^{\circ} \mathrm{C}$ converts into starting material. The dimerization proceeds via intermediates and not the ketone amine (Scheme 31).

5.4.5. Sulphur Substituents. The mesoionic 4,5-diphenyl-11,3,4-thiadiazole-2-thiolate reacts with methyl azodicarboxylate to yield the azothiadiazole and not the tetrazine betaine as previously claimed from 2-amino-5-phenyl-1,3,4-thiadiazole and nitrosobenzene (Scheme 32).

5.4.6. Amino Substituents. The reaction of unsubstituted 2amino-1,3, and 4-thiadiazole with 1,3-dicarbonyl compounds is independent of the nature of the dicarbonyl compounds. The reaction of pentane-2-4-dione gives the 4,6-dimethyl 1,2thiocyanatepyrimidine. The formation may proceed via the cation. With ethylacetoacetate, however, if a mixture formed also being converted in to on heating.

Biological Activities of 1,3,4-Thiadiazole Derivatives. During the recent years, there has been intense investigation of different classes of thiadiazole compounds, many of which possess extensive pharmacological activities. Among of these compounds having 1,3,4-thiadiazole nucleus are known to exhibit unique antimicrobial activity [25-38]. Antifungal [39-41], antidiabetic [42], anti-inflammatory [38, 43-54], antileishmanial activity [55-58], antituberculosis activity,
[59-61], anticancer activity, [34, 62-68] anti-HIV activity [69, 70], antioxidant/radioprotective Activity [71-73], Carbonic anhydrase inhibitors [74, 75]. Anti-Helicobacter pylori activity $[76,77]$. This paper focuses on the therapeutic importance of novel thiadiazole derivatives as anticonvulsant agents for future.

Anticonvulsant Activity of Thiadiazole Derivatives. A series of 3-aryl amino/amino-4-aryl-5-imino-D2-1,2,4-thiadiazole has been synthesized and screened for anticonvulsant activity. All the synthesized compounds were evaluated against maximal electroshock-induced seizure (MES) and subcutaneouspentylenetetrazole- (ScPTZ-) induced seizure models in mice. Among the compounds tested, all showed protection from MES seizures, whereas only (104) (105) was found to be active in the ScPTZ test. The present results revealed that a number of 3-aryl amino/amino-4-aryl-5-imino-D2-1,2,4thiadiazoles exhibit a range of activities in anticonvulsant screen [78].<smiles>CCOc1ccc([Al]c2cnc(C)nc2)cc1</smiles> 


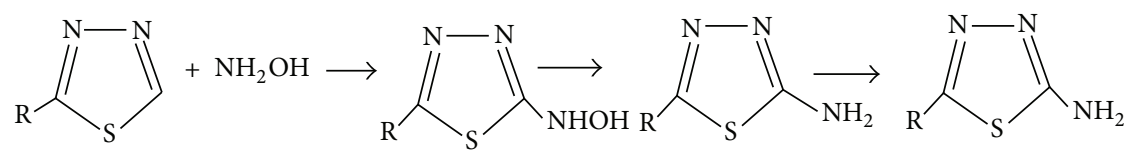

(55)

(56)

(57)

(58)

SCHeme 17<smiles></smiles>

(59)<smiles>[R17]N1NNC(=S)N1</smiles>

(60)
Scheme 18<smiles>[R]c1ccccc1/C=N/c1nnc(S)s1</smiles>

Compounds $\quad \mathrm{R}$

109a, 110ia, 110iia $\quad 2-\mathrm{Cl}$

109b, 110ib, 110iib 4-Cl

109c, 110ic, 110iic $2-\mathrm{NO}_{2}$

109d, 110id, 110iid 4- $\mathrm{NO}_{2}$

109e, 110ie, 110iie $\quad 4$-F<smiles>[R]c1ccccc1/C=N/c1nnc(SCc2ccccc2)s1</smiles><smiles>[R]c1ccccc1/C=N/c1nnc(SCc2ccc(Cl)cc2)s1</smiles>

(110iia-15iie)

A variety of new 3-[5-substituted phenyl-1,3,4-thiadiazol2-yl]-2-styryl quinazoline-4(3H)-ones were synthesized and evaluated for anticonvulsant activity $b$. Compounds were examined in the maximal-electroshock- (MES-) induced seizures and subcutaneous-pentylenetetrazole- (scPTZ-) induced seizure models. Compounds (111a), (111b), and (111c) showed good anticonvulsant activity in the test models [82].<smiles>[Y17]C=Cc1nc2ccccc2c(=O)n1-c1nnc([R])s1</smiles>

$$
\begin{aligned}
& 111 \mathbf{a}=\mathrm{R}=\mathrm{C}_{6} \mathrm{H}_{5} ; \mathrm{Ar}=4-\mathrm{ClC}_{6} \mathrm{H}_{4} \\
& 111 \mathbf{b}=\mathrm{R}=3-\mathrm{ClC}_{6} \mathrm{H}_{4} ; \mathrm{Ar}=4-\mathrm{ClC}_{6} \mathrm{H}_{4} \\
& 111 \mathbf{c}=\mathrm{R}=4-\mathrm{ClC}_{6} \mathrm{H}_{4} ; \mathrm{Ar}=\text { pyridyl }
\end{aligned}
$$

Two new series of 2,5-disubstituted-1,3,4-thiadiazoles were synthesized for their possible anticonvulsant, antibacterial, and antifungal activities. The degree of protection afforded by these compounds at a dose of $100 \mathrm{mg} / \mathrm{kg}$ i.p. against pentylenetetrazole-induced convulsions in mice ranged from $0 \%$ to $90 \%$. Among these compounds, 112a (90\%) and 112g (70\%) showed maximum protection [83].<smiles>CCNc1nnc(-c2cc3ccccc3cc2O)s1</smiles>

(112a)<smiles>Oc1cc2ccccc2cc1-c1nnc(NCCc2ccccc2)s1</smiles>

(112b)<smiles>Oc1cc2ccccc2cc1-c1nnc(Nc2ccccc2)s1</smiles>

(112c)<smiles>Oc1cc2ccccc2cc1-c1nnc(Nc2ccc(Br)cc2)s1</smiles>

(112d)<smiles>Oc1cc2ccccc2cc1-c1nnc(Nc2cccc(F)c2)s1</smiles>

$(112 \mathrm{e})$ 


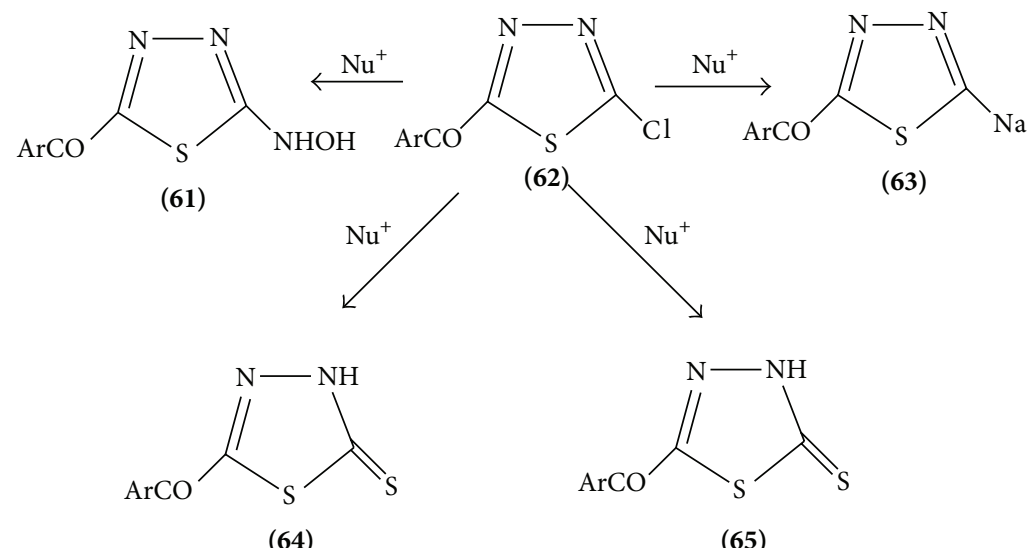

SCHEME 19<smiles>COC(=O)C(Cl)(Cl)C(=O)Cl</smiles>

(66)<smiles>CC(=O)Nc1nncs1</smiles>

$(67)$
SCHEMe 20<smiles>COc1ccc(Nc2nnc(-c3cc4ccccc4cc3O)s2)cc1</smiles>

(112f)<smiles>Oc1cc2ccccc2cc1-c1nnc(Nc2ccc(F)cc2)s1</smiles>

(112h)

3-[(2-Methyl-1H-3-indolyl)methyl]-4-aryl-4, 5-dihydro$1 H$-1,2,4-triazole-5-thiones and their respective $N-\{5-[(2-$ methyl-1H-3-indolyl)methyl]-1,3,4-thiadiazol-2-yl $\}-N$-arylamines have been prepared. Behavioral effects, induced by the members of both series, in conjunction with their activity in some specific tests (forced swim, pentetrazol convulsions) on mice, show that these derivatives cross the blood-brain barrier and could develop an antidepressant activity comparable to that of imipramine. Blood-brain barrier penetration is also supported by the lipophilicity data obtained for all analogs [84]. (Structure (113)).<smiles>CCCCCn1c(Cc2c(C)[nH]c3ccccc23)n[nH]c1=S</smiles>

(113)

Several novel 2-amino-5-[4-chloro-2-(2-chlorophenoxy)phenyl]-1,3,4-thiadiazole derivatives $4 a-d$ were synthesized, and their anticonvulsant activity was determined by evaluation of the ability of these compounds to protect mice against convulsion induced by lethal doses of pentylenetetrazole (PTZ) and maximal electroshock (MES). The result of anticonvulsant data shows that among the synthesized compounds, 5-[4-chloro-2-(2-chlorophenoxy)phenyl]-N-ethyl-1,3,4-thiadiazol-2-amine $(114,115,116)$ was the most active compound in both MES and PTZ tests with an ED50 of 20.11 and $35.33 \mathrm{mg} / \mathrm{kg}$, respectively [85].<smiles>Nc1nnc(-c2ccc(Cl)cc2Oc2ccccc2Cl)s1</smiles><smiles>CCNc1nnc(-c2ccc(Cl)cc2Oc2ccccc2Cl)s1</smiles>

(115) 
<smiles>[R]c1nnc(N)s1</smiles>

(68)<smiles>[R]c1nnc([N])s1</smiles>

Diazo compound

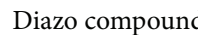<smiles>Cc1ccc(NNc2nncs2)c(C)c1</smiles>

(70)<smiles>[R]c1nnc(NNc2c(C)cccc2C)s1</smiles>

(71)

SCHEME 21<smiles>[R]c1nnc(N)s1</smiles>

(72)<smiles>[Z11]C=Nc1nnc([R])s1</smiles>

(73)
Scheme 22<smiles>[R5]c1nnc(-c2ccccc2)s1</smiles>

(74)<smiles>Sc1nnc(-c2ccccc2)s1</smiles>

(75)
Scheme 23<smiles>Clc1ccc(-c2nnc(Nc3ccccc3)s2)c(Oc2ccccc2Cl)c1</smiles>

The present study describes the synthesis and anticonvulsant activity evaluation of 6 -substituted-[1,2,4]triazolo[3,4-b][1,3,4]thiadiazole derivatives and their partially dehydrogenated products 5,6-dihydro-6-substituted$[1,2,4]$ triazolo[3, 4-b] $[1,3,4]$ thiadiazole derivatives. The bioevaluation demonstrated that most compounds in the series exhibited potent anticonvulsant activity in the maximal electroshock test. Among which, 6-(4-chlorophenyl)-[1,2, 4] triazolo[3,4-b][1,3,4] thiadiazole (117) emerged as the most promising candidate on the basis of its favorable ED50 value of $23.7 \mathrm{mg} / \mathrm{kg}$ and PI value of 10.8. In addition, the potency of compound $\mathbf{1 1 7}$ against seizures induced by pentylenetetrazole, 3-mercaptopropionic acid, and bicuculline in the chemical-induced seizure tests suggested that compound 117 displayed broad-spectrum activity in several models, and it may exert its anticonvulsant activity through affecting the GABAergic system [86].

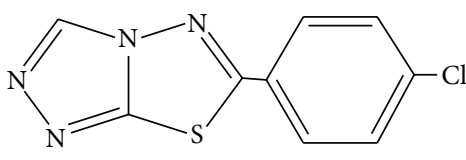

(117)

Synthesis and pharmacological evaluation of a number of substituted 1,3,4-thiadiazole the first member of the series 2-(aminomethyl)-5-(2-biphenyl)-1,3,4-thiadiazole (118) was found to possess potent anticonvulsant property in rats and mice and compared favourable with the standard anticonvulsant drug phenytoin, Phenobarbital and carbamazepine in a number of test situations. The potency of compound was maintained on alkylation of the side chain nitrogen atom; however, aryl substitution on chain lengthening caused a drop in potency replacement of the two biphenyl group by phenyl or benzyl also lead to inactive compound [87].<smiles>NCc1nnc(-c2ccccc2-c2ccccc2)s1</smiles>

(118)

Various N-(5-chloro-6-substituted-benzothiazol-2-yl)$\mathrm{N}^{\prime}$-(substituted phenyl)-[1,3,4]thiadiazole-2,5-diamines were designed and synthesized starting from substituted acetophenones. Structures of all the compounds were confirmed on the basis of spectral and elemental analyses. All the newly synthesized compounds were screened for their anticonvulsant activity and were compared with the standard drug phenytoin sodium. Interestingly, all the compounds showed protections against seizures in the range 50\%-100\% indicative of the promising nature of the compounds against seizure spread. Compound $\mathbf{1 1 9}$ showed complete protection against MES-induced seizures [88]. 


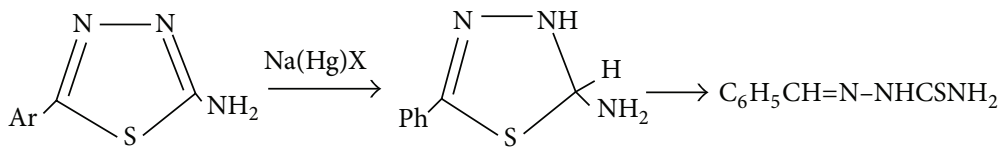<smiles>CCOC(=O)CC(=O)OCC</smiles>

(79)

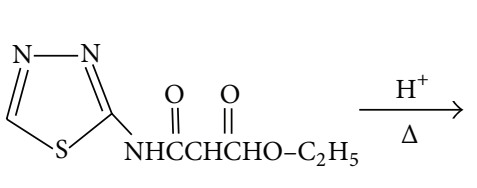

(80)<smiles>O=c1cc(O)n2ncsc2n1</smiles>

(81)

SCHEME 25<smiles>CN(N)c1nnc(-c2ccccc2-c2ccccc2)s1</smiles>

(119)

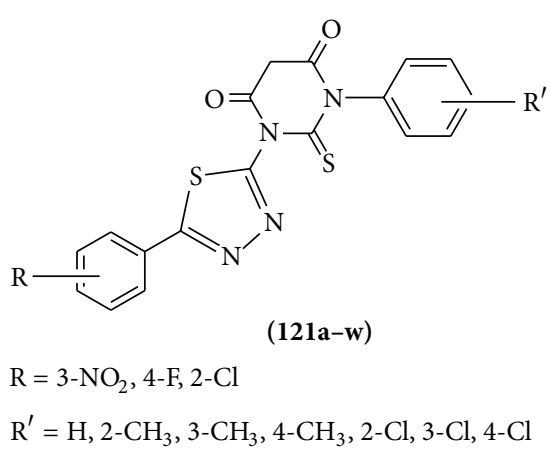

A series of 1,2,4-thiadiazoles (120a-e) were prepared and evaluated for anticonvulsant activity by Siddiqui et al. The compound with para-chloro substitution (120c) showed maximal activity in MES test and blocked strychnine seizures to some extent whereas other compounds of the series were less active [89].<smiles>[R]C[C@H](Cl)[C@H](Cl)[N+](=O)[O-]</smiles>

A series of 1-(substituted phenyl)-3-[(5-substituted phenyl)-1,3,4-thiadiazol-2-yl]-2-thioxodihydropyrimidine4,6 $(1 H, 5 H)$-diones $\mathbf{1 2 1}(\mathbf{a}-\mathbf{w})$ were designed, synthesized in good yields. The compounds were evaluated for anticonvulsant activity. The compounds were potent in MES test and were less neurotoxic as compared to standard drug phenytoin [90].
A series of thiadiazole derivatives were synthesized with differently substituted benzoic acids which were cyclized to give differently substituted thiazolidin-4-one. Elemental analysis, IR, HNMR,C NMR, and mass spectral data confirmed the structure of the synthesized compounds. The derivatives of these moieties were evaluated for anticonvulsant activity by MES model and neurotoxicity by rotarod method. The synthesized compounds showed good potential for anticonvulsant activity besides this, and the compounds also showed neurotoxic effect. It was observed that compounds with $\mathrm{OCH} 3$ at 3, 4 position of phenyl ring showed less protection against convulsions as compared to compounds having unsubstituted phenyl ring [91].

The synthesis and anticonvulsant activity of a series of 2aryl-5-hydrazino-1,3,4-thiadiazoles are described. The combination of preferred aromatic substituents in the 2-position coupled with alkyl substitution on the hydrazine moiety led to a number of potent compounds lacking sedation, ataxia, or lethality. 5-(2-Biphenylyl)-2-(1-methylhydrazino)1,3,4-thiadiazole $(4 \mathrm{~m})$ represents a new class of anticonvulsant agent and compares favorably with the standard drugs phenytoin, phenobarbital, and carbamazepine [92] (Structure (122)). 


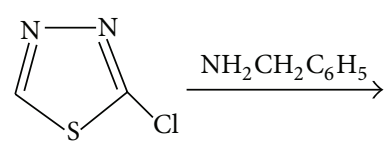

(82)<smiles>c1ccc(CNc2nncs2)cc1</smiles>

(83)

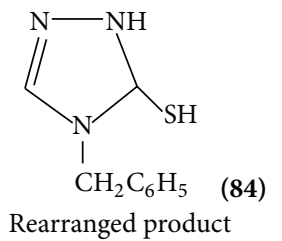

Rearranged product

SCHEME 26<smiles>[R]C1=NNC(S)N1N</smiles>

(85)

(86)

SCHEME 27<smiles>[R]c1nnc(N)s1</smiles>

(87)<smiles>C=C1NN=C(N)S1</smiles>

(88)<smiles>Nc1nnc([SH2+])n1N</smiles>

(89)

SCHEME 28<smiles>[R]c1nnc(N(N)Cc2ccccc2)s1</smiles>

(91)<smiles>[R]c1nn(Cc2ccccc2)c(=S)n1N</smiles>

(92)

SCHEME 29<smiles>[R19]c1nn([R2])c(=S)s1</smiles>

(93)

(94)

(95)

SCHEME 30

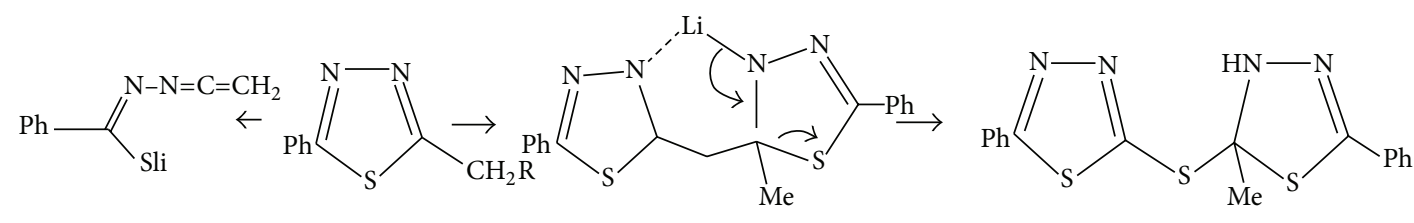

(96)
(98)

(99)

Scheme 31 
<smiles>[S-]c1nnc[pH]1</smiles>

(100)<smiles>CC(=O)/N=N\C(C)=O</smiles>

(101)

$\downarrow$<smiles>[S-]c1nnc[nH+]n1</smiles>

(103)<smiles>[Nb]=Nc1nncs1</smiles>

(102)

SCHEME 32<smiles>CN(N)c1nnc(-c2ccccc2-c2ccccc2)s1</smiles>

(122)

A novel series of $\mathrm{NN}^{\prime}-\{5$-[(1H-indol-3-ylmethyl)-1,3,4thiadiazol]-2-yl\}-N4-(4-substituted benzaldehyde) semicarbazones, N1-\{5-[(1H-indol-3-ylmethyl)-1,3,4-thiadiazol-2yl\}-N4-[1-(4-substituted phenyl)ethanone]-semicarbazones and N1-\{5-[(1H-indol-3-ylmethyl)-1,3,4-thiadiazol-2-yl $\}$ N4-[1-(4-substituted phenyl) (phenyl) methanone]-semicarbazones were synthesized and evaluated for their anticonvulsant potential using maximal electroshock seizure (MES) and subcutaneous pentylenetrtrazole (scPFZ) models. The minimal motor impairment (neurotoxicity) was determined by rotarod test. The results of the present study confirmed the requirements of various structural features of four binding site pharmacophore model for anticonvulsant activity [93].

Treatment of 2-bromoacetylbenzofuran with $1 \mathrm{H}$-benzotriazole afforded 1-(benzofuran-2-yl)-2-(benzotriazol-1-yl) ethanone which reacted with phenylisothiocyanate to give the corresponding thioacetanilide derivatives. Treatment of the latter ethanone and thioacetanilide derivatives with hydrazonoyl chlorides afforded the corresponding pyrazole and 1,3,4-thiadiazolederivatives. The thioacetanilide derivative reacted with $\alpha$-haloketones and $\alpha$-halodiketones to afford thiophene and thiazole derivatives, respectively. The newly synthesized compounds were found to possess anticonvulsant and anti-inflammatory activities with the same mechanism of action of selective COX-2 inhibitors [94].

\section{References}

[1] W. Loscher, "New visions in the pharmacology of anticonvulsion," European Journal of Pharmaceutical Sciences, vol. 342, pp. $1-13,1998$.

[2] A. Gringauz John Wiley \& Sons, New York, NY, USA, 1st edition, 1997.
[3] M. J. Brodie, "Monotherapy trials: prerequisite data," Epilepsy Research, vol. 45, no. 1-3, pp. 61-64, 2001.

[4] R. H. Mattson, "Efficacy and adverse effects of established and new antiepileptic drugs," Epilepsia, vol. 36, supplement 2, pp. S13-S26, 1995.

[5] A. Demirbas, D. Sahin, N. Demirbas, and S. A. Karaoglu, "Synthesis of some new 1,3,4-thiadiazol-2-ylmethyl-1,2,4-triazole derivatives and investigation of their antimicrobial activities," European Journal of Medicinal Chemistry, vol. 44, no. 7, pp. 2896-2903, 2009.

[6] R. T. Morrison and R. N. Boyd, Organic Chemistry, Prentice Hall, New Delhi, India, 6th edition, 2005.

[7] T.-B. Wei, H. Liu, J.-H. Hu et al., "Microwave promoted efficient synthesis of 2,5-disubstituted 1,3,4-thiadiazole," Indian Journal of Chemistry B, vol. 45, pp. 2754-2756, 2006.

[8] J. Goerdler, J. Ohm, and O. Tegmeyer, "Darstellung und Eigenschaften des 1.2.4- und des 1.3.4-Thiodiazols," Chemische Berichte, vol. 89, pp. 1534-1543, 1956.

[9] A. R. Katritzky and R. Charlews, in Comprehensive Heterocyclic Chemistry, vol. 6, pp. 568-575, Ist edition, 1984.

[10] E. Formm, E. Layer, and K. Nerz, Advances in Heterocyclic Chemistry, vol. 9, p. 188, 1968.

[11] H. B. Koing and H. A. Ofle, Chemical Abstracts, vol. 53, p. 10253, 1957.

[12] British Patent, Chemical abstract, 59, 1650, 916061, 1963.

[13] F. Kurzer, "Thiadiazoles. Part XI. Synthesis and cyclisation of N(thiobenzamido)guanidines and related compounds," Journal of the Chemical Society, vol. 1961, pp. 1617-1625, 1961.

[14] R. R. Gupta, M. Kumar, and V. Gupta, Heterocyclic Chemistry Springen, vol. 2, pp. 566-573, 2005.

[15] G. Young and W. Eyne, "III.-Oxidation of benzalthiosemicarbazone," Journal of the Chemical Society, Transactions, vol. 79, pp. 54-60, 1901.

[16] J. Y. Hweng, H. Choi, D. H. Lee, and Y. D. Gong, "Solid-phase synthesis of 1,3,4-oxadiazole and 1,3,4-thiadiazole derivatives via selective, reagent-based cyclization of acyldithiocarbazate resins," Journal of Combinatorial Chemistry, vol. 7, pp. 816-819, 2005.

[17] P. C. Guha, "Ring closure of hydrazodithio- and -monothiodicarbonamides with acetic anhydride," Journal of the American Chemical Society, vol. 45, pp. 1036-1042, 1923. 
[18] T. A. Bachetti and B. J. Banieli, Advances in Heterocyclic Chemistry, vol. 9, p. 1711, 1968.

[19] J. Goerdeler and H. Hanbrich, "Über die Kupplungsaktivität einiger heterocyclischer Diazoverbindungen," Chemische Berichte, vol. 93, pp. 397-405, 1960.

[20] M. Otha, H. Oya, and A. J. Miture, Charm Soc Japan Chemical Abstract, vol. 48, p. 10006, 1953.

[21] C. J. Anisworth, "The investigation of some substituted 1,3,4thiadiazoles," Journal of the American Chemical Society, vol. 80, no. 19, p. 5201, 1958.

[22] F. F. Medovschikowa and I. Y. Postovskii, Journal of Heterocyclic Chemistry, vol. 9, p. 197, 1968.

[23] H. Sai Kachi and M. Kanaka, Yakugakuzasthi Chemi Abstract, vol. 58, p. 4543, 1963.

[24] H. Sai Kachi and M. Kanaka, Yakugakuzasthi, vol. 58, p. 7304, 1962.

[25] S. N. Swamy, Basappa, B. S. Priya et al., "Synthesis of pharmaceutically important condensed heterocyclic 4,6-disubstituted1,2,4-triazolo-1,3,4-thiadiazole derivatives as antimicrobials," European Journal of Medicinal Chemistry, vol. 41, no. 4, pp. 531$538,2006$.

[26] S. Hussain, J. Sharma, and M. Amir, "Synthesis and antimicrobial activities of 1,2,4-triazole and 1,3,4-thiadiazole derivatives of 5-amino-2-hydroxybenzoic acid," E-Journal of Chemistry, vol. 5, no. 4, pp. 963-968, 2008.

[27] A. A. Aly and R. E. Sayed, "Synthesis and biological activity of new 1,3,4-thiadiazole derivatives," Chemical Papers, vol. 60, no. 1, pp. 56-60, 2006.

[28] R. Dua and S. K. Srivastava, "Synthesis, characterization and antimicrobial activity," International Journal of Pharma and Bio Sciences, vol. 1, no. 2, 2010.

[29] F. Hadizadeh and R. Vosooghi, "Synthesis of $\alpha$-[5-(5-amino1,3,4-thiadiazol-2-yl)-2-imidazolylthio] acetic acids," Journal of Heterocyclic Chemistry, vol. 45, no. 5, pp. 1477-1479, 2008.

[30] J. Salimon, N. Salih, A. Hameed, H. Ibraheem, and E. Yousif, "Synthesis and antibacterial activity of some new 1,3,4oxadiazole and 1,3,4-thiadiazole derivatives," Journal of Applied Sciences Research, vol. 6, no. 7, pp. 866-870, 2010.

[31] A. M. Qandil, H. N. Tumah, and M. A. Hassan, "Synthesis and antibacterial activity of N4-benzoyl-N 1-dihydroxybenzoylthiosemicarbazides and their cyclic 1,3,4-thiadiazole derivatives," Acta Pharmaceutica Sciencia, vol. 48, no. 2, pp. 95107, 2006.

[32] R. S. Lamani, N. S. Shetty, R. R. Kambl, and A. M. Khazi, "Synthesis and antimicrobial studies of novel methylene bridged benzisoxazolyl imidazo[2,1- $b][1,3,4]$ thiadiazole derivatives," European Journal of Medicinal Chemistry, vol. 44, pp. 2828-2833, 2008.

[33] A. Foroumadi, S. Emami, A. Hassanzadeh et al., "Synthesis and antibacterial activity of N-(5-benzylthio-1,3,4-thiadiazol-2yl) and N-(5-benzylsulfonyl-1,3,4-thiadiazol-2-yl)piperazinyl quinolone derivatives," Bioorganic and Medicinal Chemistry Letters, vol. 15, no. 20, pp. 4488-4492, 2005.

[34] T. Onkol, D. S. Doruer, L. Uzun, S. Adak, S. Ozkan, and M. F. Ahin, "Synthesis and antimicrobial activity of new 1,2,4-triazole and 1,3,4-thiadiazole derivatives," Journal of Enzyme Inhibition and Medicinal Chemistry, vol. 23, no. 2, pp. 277-284, 2008.

[35] N. Siddiqui and M. S. Alam, "5-(1H-indol-3-ylmethyl)-N-(substituted phenyl)-1, 2, 4-thiadiazol-2-amine derivatives: synthesis and biological screening," Biosciences Biotechnology Research Asia, vol. 6, no. 1, pp. 261-264, 2009.
[36] P. Karegoudar, D. J. Prasad, M. Ashok, M. Mahalinga, B. Poojary, and B. S. Holla, "Synthesis, antimicrobial and anti-inflammatory activities of some 1,2,4-triazolo[3,4-b][1,3,4] thiadiazoles and 1,2,4-triazolo[3,4-b][1,3,4]thiadiazines bearing trichlorophenyl moiety," European Journal of Medicinal Chemistry, vol. 43, no. 4, pp. 808-815, 2008.

[37] T. Karabasanagouda, A. V. Adhikari, and N. S. Shetty, "Synthesis and antimicrobial activities of some novel 1,2,4-triazolo[3,4- $b]$ 1,3,4-thiadiazoles and 1,2,4-triazolo[3,4- $b]$-1,3,4-thiadiazines carrying thioalkyl and sulphonyl phenoxy moieties," European Journal of Medicinal Chemistry, vol. 42, no. 4, pp. 521-529, 2007.

[38] V. Mathew, J. Keshavayya, V. P. Vaidya, and D. Giles, "Studies on synthesis and pharmacological activities of 3,6-disubstituted1,2,4-triazolo[3,4- $b]$-1,3,4-thiadiazoles and their dihydro analogues," European Journal of Medicinal Chemistry, vol. 42, no. 6, pp. 823-840, 2007.

[39] C. J. Chen, B. A. Song, S. Yang et al., "Synthesis and antifungal activities of 5-(3,4,5-trimethoxyphenyl)-2-sulfonyl-1,3,4thiadiazole and 5-(3,4,5-trimethoxyphenyl)-2-sulfonyl-1,3,4oxadiazole derivatives," Bioorganic and Medicinal Chemistry, vol. 15, pp. 3981-3989, 2007.

[40] H. S. Chen, H. S. LI, H. S. Z, Y. F. Han, and Z. W. Wang, "New fungicidally active pyrazolyl-substituted 1,3,4-thiadiazole compounds and their preparation," Chinese Chemical Letters, vol. 10, no. 5, pp. 365-366, 1999.

[41] M. Barboiu, M. Cimpoesu, C. Guran, and C. T. Supumn, "1, 3, 4-thiadiazole derivatives. Part $9^{1}$. Synthesis and biological activity of metal complexes of 5-(2-aminoethyl)-2-amino-1,3,4thiadiazole," Metal Based Drugs, vol. 3, no. 5, pp. 227-232, 1996.

[42] S. R. Pattan, P. kekare, N. S. Dighe et al., "Synthesis and biological evaluation of some 1,3,4-thiadiazoles," Journal of Chemical and Pharmaceutical Research, vol. 1, no. 1, pp. 191-198, 2009.

[43] M. Amir, H. Kumar, and S. A. Javed, "Condensed bridgehead nitrogen heterocyclic system: Synthesis and pharmacological activities of 1,2,4-triazolo-[3,4-b]-1,3,4-thiadiazole derivatives of ibuprofen and biphenyl-4-yloxy acetic acid," European Journal of Medicinal Chemistry, vol. 43, no. 10, pp. 2056-2066, 2008.

[44] M. Amir, H. Kumar, and S. A. Javed, "Synthesis and pharmacological evaluation of condensed heterocyclic 6-substituted1,2,4-triazolo[3,4-b]-1,3,4-thiadiazole derivatives of naproxen," Bioorganic and Medicinal Chemistry Letters, vol. 17, pp. 45044508, 2007.

[45] L. S. Varandas, C. A. M. Fraga, A. L. P. Miranda, and E. J. Barreiro, "Design, synthesis and pharmacological evaluation of new nonsteroidal antiinflammatory 1,3,4-thiadiazole derivatives," Letters in Drug Design and Discovery, vol. 2, no. 1, pp. 6267, 2005.

[46] M. Moise, V. Sunel, L. Profire, M. Popa, J. Desbrieres, and C. Peptu, "Synthesis and biological activity of some new 1,3,4-thiadiazole and 1,2,4-triazole compounds containing a phenylalanine moiety," Molecules, vol. 14, no. 7, pp. 2621-2631, 2009.

[47] H. Kumar, S. A. Javed, S. A. Khan, and M. Amir, "1,3,4Oxadiazole/thiadiazole and 1,2,4-triazole derivatives of biphenyl-4-yloxy acetic acid: Synthesis and preliminary evaluation of biological properties ", European Journal of Medicinal Chemistry, vol. 43, no. 12, pp. 2688-2698, 2008.

[48] S. Schenone, C. Brullo, O. Bruno et al., "New 1,3,4-thiadiazole derivatives endowed with analgesic and anti-inflammatory activities," Bioorganic and Medicinal Chemistry, vol. 14, no. 6, pp. 1698-1705, 2006. 
[49] S. G. Kucukguzel, I. Kucukguze, I. E. Tatar et al., "Synthesis of some novel heterocyclic compounds derived from diflunisal hydrazide as potential anti-infective and anti-inflammatory agents," European Journal of Medicinal Chemistry, vol. 42, no. 7, pp. 893-901, 2007.

[50] M. A. Hilfiker, N. Wang, X. Hou et al., "Discovery of novel aminothiadiazole amides as selective EP3 receptor antagonists," Bioorganic and Medicinal Chemistry Letters, vol. 19, no. 15, pp. 4292-4295, 2009.

[51] A. K. Gadad, M. B. Palkar, K. Anand, M. N. Noolvi, T. S. Boreddy, and J. Wagwade, "Synthesis and biological evaluation of 2-trifluoromethyl/sulfonamido-5,6-diaryl substituted imidazo[2,1-b]-1,3,4-thiadiazoles: a novel class of cyclooxygenase-2 inhibitors," Bioorganic and Medicinal Chemistry, vol. 16, no. 1, pp. 276-283, 2008.

[52] U. S. Goksen, N. G. Kelekci, O. Goktas et al., "1-Acylthi-osemicarbazides, 1,2,4-triazole-5(4H)-thiones, 1,3,4-thiadiazoles and hydrazones containing 5-methyl-2-benzoxazolinones: synthesis, analgesic-anti-inflammatory and antimicrobial activities," Bioorganic and Medicinal Chemistry, vol. 15, no. 17, pp. 57385751, 2007.

[53] A. S. Kalgutar, A. B. Marnett, B. C. Crews, R. P. Remmel, and L. J. Marnett, "Ester and Amide derivatives of the nonsteroidal antiinflammatory drug, indomethacin, as selective cyclooxygenase2 inhibitors," Journal of Medicinal Chemistry, vol. 43, no. 15, pp. 2860-2870, 2000.

[54] M. Duflos, M. R. Nourrisson, J. Brelet et al., "N-Pyridinylindole-3-(alkyl)carboxamides and derivatives as potential systemic and topical inflammation inhibitors," European Journal of Medicinal Chemistry, vol. 36, no. 6, pp. 545-553, 2001.

[55] V. J. Ram, A. Goel, and M. Kandpal, "Tetraazaacenaphthene, tetraazaphenalene and 1,3,4-thiadiazole derivatives as potential leishmanicides," Bioorganic and Medicinal Chemistry Letters, vol. 7, no. 6, pp. 651-656, 1997.

[56] E. F. da Silva, M. M. Canto-Cavalheiro, V. R. Braz, L. CysneFinkelstein, L. L. Leon, and A. Echevarria, "Synthesis, and biological evaluation of new 1,3,4-thiadiazolium-2-phenylamine derivatives against Leishmania amazonensis promastigotes and amastigotes," European Journal of Medicinal Chemistry, vol. 37, no. 12, pp. 979-984, 2002.

[57] M. Behrouzi-Fardmoghadam, F. Poorrajab, S. K. Ardestani, S. Emami, A. Shafiee, and A. Foroumadi, "Synthesis and in vitro anti-leishmanial activity of 1-[5-(5-nitrofuran-2-yl)1,3,4-thiadiazol-2-yl]- and 1-[5-(5-nitrothiophen-2-yl)-1,3,4thiadiazol-2-yl]-4-aroylpiperazines," Bioorganic and Medicinal Chemistry, vol. 16, no. 8, pp. 4509-4515, 2008.

[58] A. Foroumadi, S. Emami, S. Pournourmohammadi, A. Kharazmi, and A. Shafiee, "Synthesis and in vitro leishmanicidal activity of 2-(1-methyl-5-nitro-1H- imidazol-2-yl)-5substituted-1,3,4-thiadiazole derivatives," European Journal of Medicinal Chemistry, vol. 40, no. 12, pp. 1346-1350, 2005.

[59] S. Karakus and S. Rollas, "Synthesis and antituberculosis activity of new N-phenyl-N'-[4-(5-alkyl/arylamino-1,3,4-thiadiazole2-yl)phenyl]thioureas," Il Farmaco, vol. 57, no. 7, pp. 577-581, 2002.

[60] E. E. Oruc, S. Rollas, F. Kandermirli, N. Shvets, and A. S. Dimoglo, "1,3,4-thiadiazole derivatives. Synthesis, structure elucidation, and structure-antituberculosis activity relationship investigation," Journal of Medicinal Chemistry, vol. 47, pp. 6760-6676, 2004.

[61] A. Foroumadi, Z. Kargar, A. Sakhteman et al., "Synthesis and antimycobacterial activity of some alkyl [5-(nitroaryl)-1,3, 4-thiadiazol-2-ylthio]propionates," Bioorganic and Medicinal Chemistry Letters, vol. 16, no. 5, pp. 1164-1167, 2006.

[62] S. Karakus, U. Coruh, B. Barlas-Durgun et al., "Synthesis and cytotoxic activity of some 1,2,4-triazoline-3-thione and 2,5disubstituted-1,3,4-thiadiazole derivatives," Marmara Pharmaceutical Journal, vol. 14, no. 2, pp. 84-90, 2010.

[63] J. Matysiak and A. Opolski, "Synthesis and antiproliferative activity of N-substituted 2-amino-5-(2,4-dihydroxyphenyl)1,3,4-thiadiazoles," Bioorganic and Medicinal Chemistry, vol. 14, no. 13, pp. 4483-4489, 2006.

[64] V. Padmavathi, G. Sudhakar Reddy, A. Padmaja, P. Kondaiah, and Ali-Shazia, "Synthesis, antimicrobial and cytotoxic activities of 1,3,4-oxadiazoles, 1,3,4-thiadiazoles and 1,2,4-triazoles," European Journal of Medicinal Chemistry, vol. 44, no. 5, pp. 2106-2112, 2009.

[65] M. X. Wei, L. Feng, X. Q. Li, X. Z. Zhou, Z.-H. Shao, and H. Shao, "Synthesis of new chiral 2,5-disubstituted 1,3,4-thiadiazoles possessing $\gamma$-butenolide moiety and preliminary evaluation of in vitro anticancer activity," European Journal of Medicinal Chemistry, vol. 44, no. 8, pp. 3340-3344, 2009.

[66] D. A. Ibrahim, "Synthesis and biological evaluation of 3,6disubstituted $[1,2,4]$ triazolo[3,4-b] $[1,3,4]$ thiadiazole derivatives as a novel class of potential anti-tumor agents," European Journal of Medicinal Chemistry, vol. 44, pp. 2776-2781, 2009.

[67] J. Matysiak, A. Nasulewicz, M. Pelczynska, M. Switalska, I. Jaroszewicz, and A. Opolski, "Synthesis and antiproliferative activity of some 5-substituted 2-(2,4-dihydroxyphenyl)-1,3,4thiadiazoles ," European Journal of Medicinal Chemistry, vol. 41, pp. 475-482, 2006.

[68] A. T. Mavrova, D. Wesselinova, Y. A. Tsenov, and P. Denkova, "Synthesis, cytotoxicity and effects of some 1,2,4-triazole and 1,3,4-thiadiazole derivatives on immunocompetent cells," European Journal of Medicinal Chemistry, vol. 44, no. 1, pp. 63-69, 2009.

[69] P. Zhan, X. Liu, Z. Li et al., "Novel 1,2,3-thiadiazole derivatives as HIV-1 NNRTIs with improved potency: synthesis and preliminary SAR studies," Bioorganic and Medicinal Chemistry, vol. 17, pp. 5920-5927, 2009.

[70] P. Zhan, X. Liu, Z. Fang, Z. Li, C. Pannecouque, and E. D. Clercq, "Synthesis and anti-HIV activity evaluation of 2-(4(naphthalen-2-yl)-1,2,3-thiadiazol-5-ylthio)- $\mathrm{N}$-acetamides as novel non-nucleoside HIV-1 reverse transcriptase inhibitors," European Journal of Medicinal Chemistry, vol. 44, pp. 46484653, 2009.

[71] C. Kus, G. A. Kilcigil, S. Ozbey et al., "Synthesis and antioxidant properties of novel $N$-methyl-1,3,4-thiadiazol-2-amine and 4methyl-2H-1,2,4-triazole-3(4H)-thione derivatives of benzimidazole class," Bioorganic and Medicinal Chemistry, vol. 16, pp. 4294-4303, 2008.

[72] S. Dhanya, A. M. Isloor, P. Shetty, K. Satyamoorthy, and A. S. Bharath Prasad, Arabian Journal of Chemistry. In press.

[73] D. Cressier, C. Prouillac, P. Hernandez et al., "Synthesis, antioxidant properties and radioprotective effects of new benzothiazoles and thiadiazoles," Bioorganic and Medicinal Chemistry, vol. 17, no. 14, pp. 5275-5284, 2009.

[74] V. Dudutien, L. Baranauskien, and D. Matulis, "Benzimidazo[1,2-c] $[1,2,3]$ thiadiazole-7-sulfonamides as inhibitors of carbonic anhydrase," Bioorganic and Medicinal Chemistry Letters, vol. 17, pp. 3335-3338, 2007.

[75] G. L. Almajan, A. Innocenti, L. Puccetti et al., "Carbonic anhydrase inhibitors. Inhibition of the cytosolic and tumorassociated carbonic anhydrase isozymes I, II, and IX with 
a series of 1,3,4-thiadiazole- and 1,2,4-triazole-thiols," Bioorganic and Medicinal Chemistry Letters, vol. 15, no. 9, pp. 23472352, 2005.

[76] J. Mirzaei, F. Siavoshi, S. Emami et al., "Synthesis and in vitro anti-Helicobacter pylori activity of N-[5-(5-nitro-2heteroaryl)-1,3,4-thiadiazol-2-yl]thiomorpholines and related compounds," European Journal of Medicinal Chemistry, vol. 43, no. 8, pp. 1575-1580, 2008.

[77] A. Foroumadi, A. Rineh, S. Emami et al., "Synthesis and antiHelicobacter pylori activity of 5-(nitroaryl)-1,3,4-thiadiazoles with certain sulfur containing alkyl side chain," Bioorganic and Medicinal Chemistry Letters, vol. 18, no. 11, pp. 3315-3320, 2008.

[78] A. Gupta, P. Mishra, S. K. Kashaw, V. Jatav, and J. P. Stables, "Synthesis and anticonvulsant activity of some novel 3-aryl amino/amino-4-aryl-5-imino- $\Delta$ 2-1,2,4-thiadiazoline," European Journal of Medicinal Chemistry, vol. 43, no. 4, pp. 749-754, 2008.

[79] A. Gupta, P. Mishra, S. N. Pandeya, S. K. Kashaw, V. Kashaw, and J. P. Stables, "Synthesis and anticonvulsant activity of some substituted 1,2,4-thiadiazoles," European Journal of Medicinal Chemistry, vol. 44, no. 3, pp. 1100-1105, 2009.

[80] M. S. Yar and M. W. Akhter, "Synthesis and anticonvulsant activity of substituted oxadiazole and thiadiazole derivatives," Acta Poloniae Pharmaceutica, vol. 66, no. 4, pp. 393-397, 2009.

[81] B. Ahamad and M. Yusuf, "synthesis of aromatic aldehyde imine derivative of 2-thiobenzyl-1,3,4-thiadiazole and evaluation of their anticonvulsant activity," Indian Journal of Chemistry B, vol. 49, pp. 241-246, 2010.

[82] V. Jatav, P. Mishra, S. Kashaw, and J. P. Stables, "CNS depressant and anticonvulsant activities of some novel 3-[5-substituted 1,3,4-thiadiazole-2-yl]-2-styryl quinazoline-4(3H)-ones," European Journal of Medicinal Chemistry, vol. 43, pp. 1945-1954, 2008.

[83] H. N. Dogan, A. Duran, S. Rollas, G. Sener, M. K. Uysal, and D. Gulen, "Synthesis of new 2, 5-disubstituted-1, 3, 4-thiadiazoles and preliminary evaluation of anticonvulsant and antimicrobial activities," Bioorganic \& Medicinal Chemistry, vol. 10, no. 9, pp. 2893-2898, 2002.

[84] A. Varvaresou, T. Siatra-Papastaikoudi, A. Tsotinis, A. T. Kakoulidou, and A. Vamvakides, "Synthesis, lipophilicity and biological evaluation of indole-containing derivatives of 1,3,4thiadiazole and 1,2,4-triazole," Il Farmaco, vol. 53, no. 5, pp. 320326,1998

[85] A. Foroumadi, V. Sheibani, A. Sakhteman et al., "Synthesis and anticonvulsant activity of novel 2-amino-5-[4-chloro-2(2- chlorophenoxy) phenyl]-1,3,4-thiadiazole derivatives," Daru Journal of Pharmaceutical Sciences, vol. 15, no. 2, pp. 89-93, 2007.

[86] X. Q. Deng, Z. Q. Dong, M. X. Song, B. Shu, S. B. Wang, and Z. S. Quan, "Synthesis and anticonvulsant activities of some triazolothiadiazole derivatives," Archiv der Pharmazie, vol. 345, no. 7, pp. 565-573, 2012.

[87] M. R. Stillings, P. W. Anthony, and S. W. Donald, "Substituted 1,3,4-thiadiazoles with anticonvulsant activity. 2. Aminoalkyl derivatives," Journal of Medicinal Chemistry, vol. 29, no. 11, pp. 2280-2284, 1986.

[88] N. Siddiqui, A. Rana, S. Khan et al., "Synthesis and preliminary screening of benzothiazol-2-yl thiadiazole derivatives for anticonvulsant activity," Acta Pharmaceutica, vol. 59, no. 4, pp. 441$451,2009$.
[89] N. Siddiqui, S. Ali, S. A. Khan, S. Drabu, A. Rana, and M. Alam, "Synthesis of 3-arylamino-4-aryl-5-(N-arylthiocarbonylimino)-4, 5-dihydro-1,2,4-thiadiazoles as anticonvulsant agents," Indian Journal of Heterocyclic Chemistry, vol. 14, no. 2, pp. 159-160, 2004.

[90] N. Siddiqui, M. F. Arshad, S. A. Khan, and W. Ahsan, "Synthesis, anticonvulsant and neurotoxicity screening of 1-(substituted phenyl)-3-[(5-substituted phenyl)-1,3,4-thiadiazole-2-yl]-2thioxodihydro pyrimidine-4,6 $(1 \mathrm{H}, 5 \mathrm{H})$-diones," Journal of Pharmaceutical Research, vol. 7, no. 2, pp. 122-125, 2008.

[91] P. Mullick, S. A. Khan, S. Verma, and O. Alam, "Thiadiazole derivatives as potential anticonvulsant agents," Bulletin of the Korean Chemical Society, vol. 32, no. 3, pp. 1011-1016, 2011.

[92] C. B. Chapleo, P. L. Mayers, J. F. Saville et al., "Substituted 1,3,4thiadiazoles with anticonvulsant activity. 1. Hydrazines," Journal of Medicinal Chemistry, vol. 29, no. 11, pp. 2273-2280, 1986.

[93] H. Rajak, C. K. Behera, R. S. Pawar, P. K. Singour, and M. D. Kharya, "Synthesis and anticonvulsant evaluation of some novel 2,5-disubstituted 1,3,4-thiadiazoles: pharmacophore model studies," Acta Poloniae Pharmaceutica, vol. 67, no. 5, pp. 503-510, 2010.

[94] M. D. Kamal, H. A. Gawad, E. A. Rageb, M. Ellithey, and H. A. Mohamed, "Synthesis, anticonvulsant, and anti-inflammatory evaluation of some new benzotriazole and benzofuran-based heterocycles," Bioorganic and Medicinal Chemistry, vol. 14, no. 11, pp. 3672-3680, 2006. 

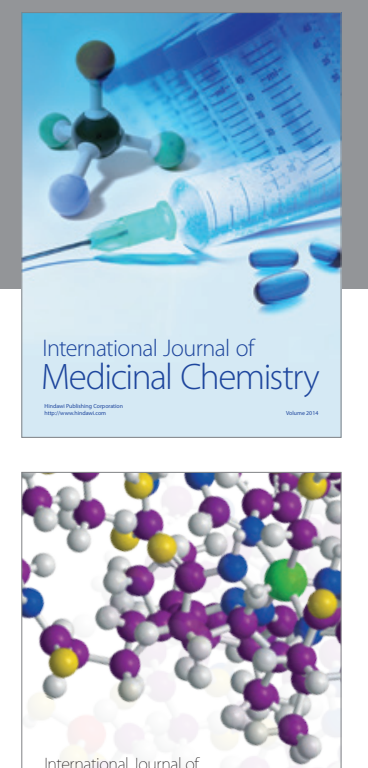

\section{Carbohydrate} Chemistry

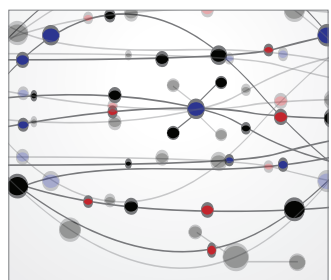

The Scientific World Journal
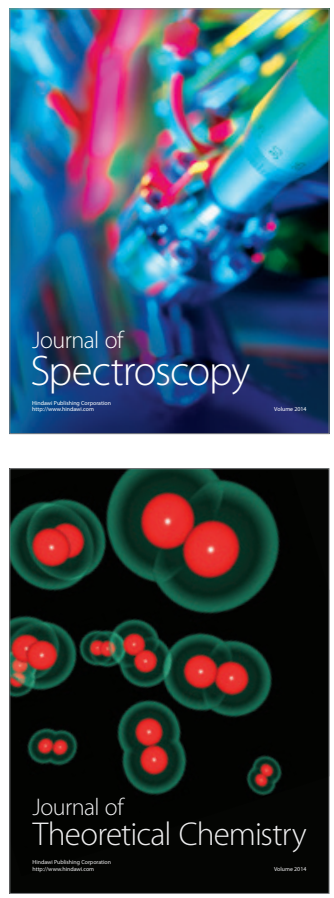
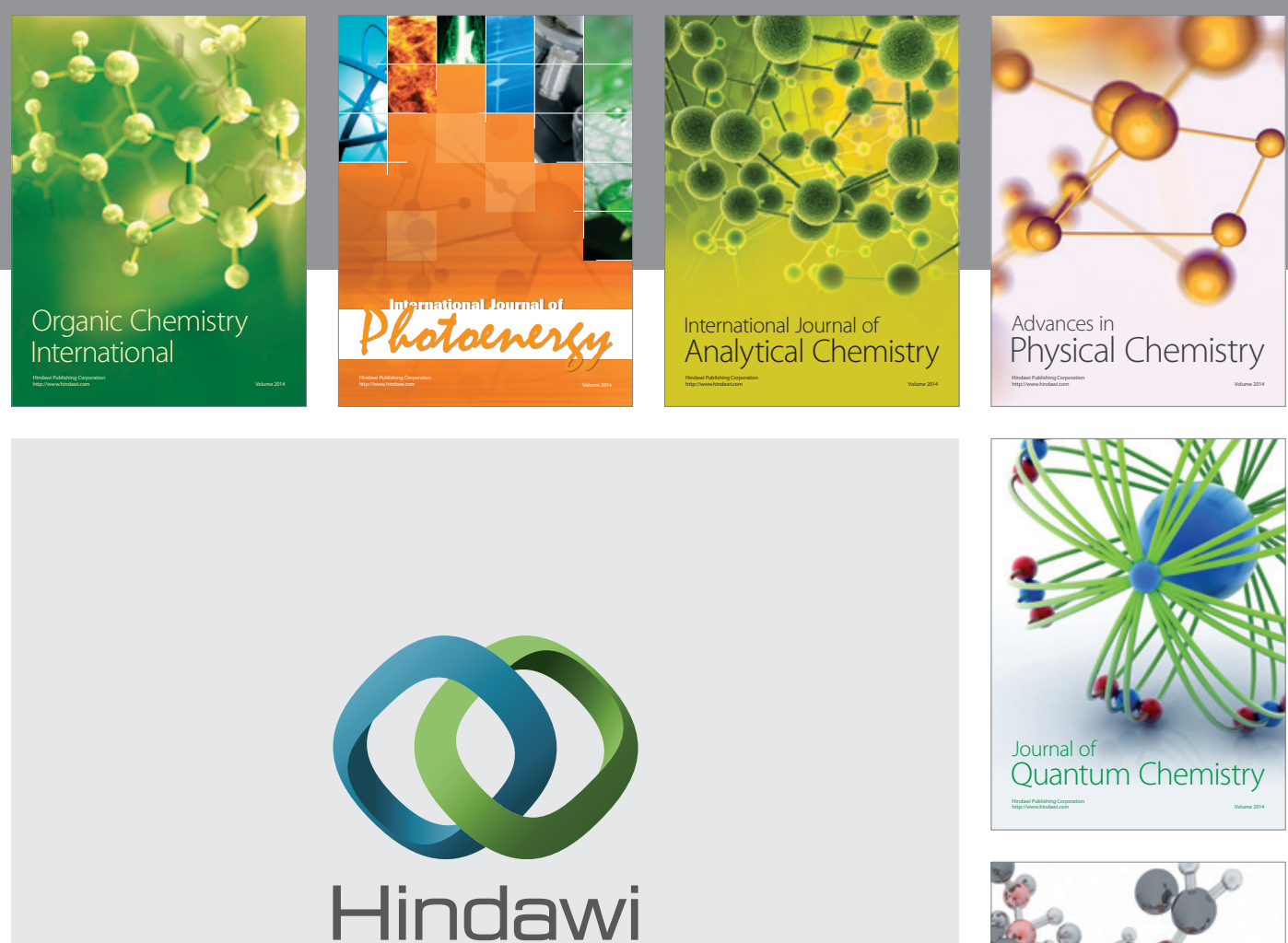

Submit your manuscripts at

http://www.hindawi.com

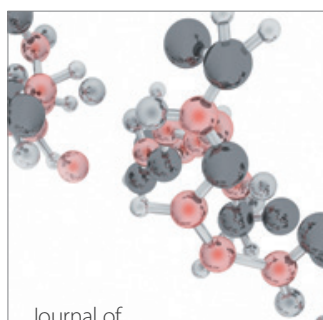

Analytical Methods

in Chemistry

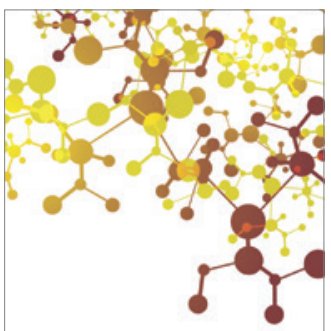

Journal of

Applied Chemistry

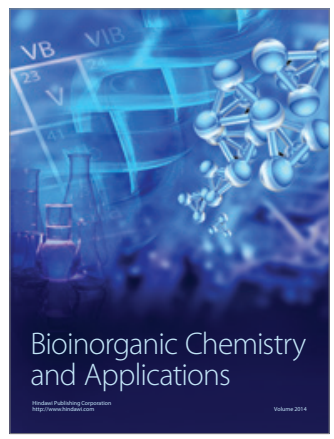

Inorganic Chemistry
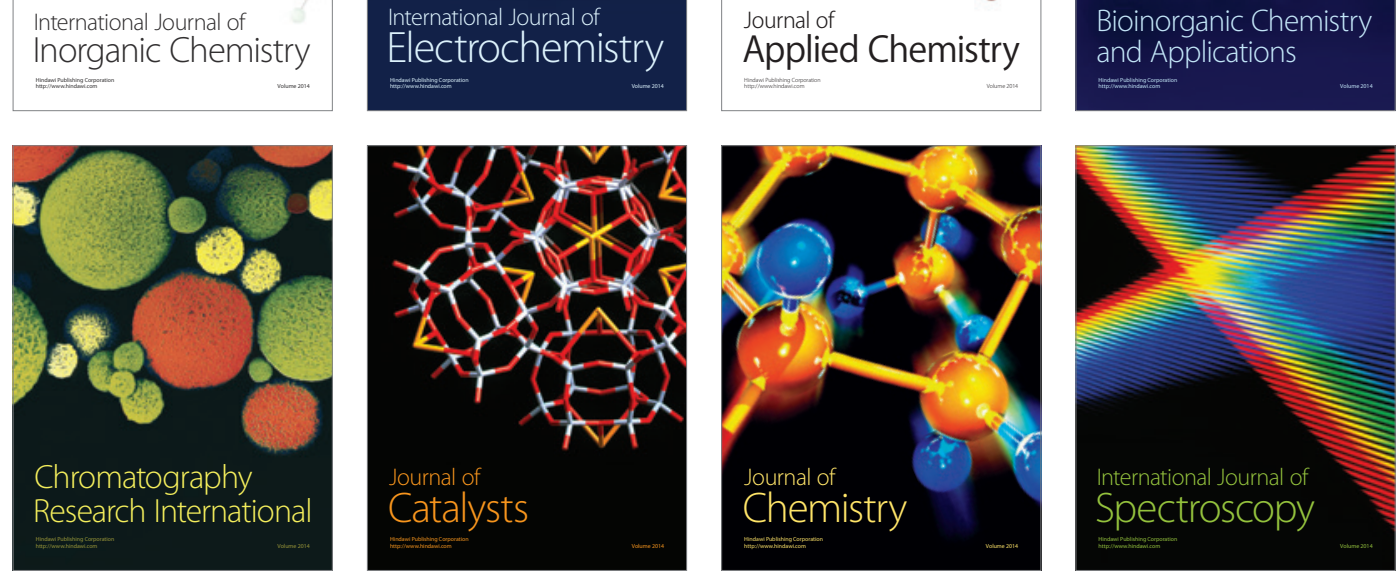